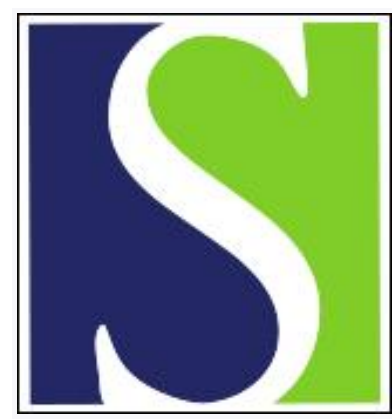

Scand J Work Environ Health 1984;10(4):267-268

https://doi.org/10.5271/sjweh.2331

Issue date: Aug 1984

Differences in the respiratory capacity of workers with long-term exposure to vapors from paints free from or containing organic isocyanates.

by Beving $\mathrm{H}$, Malmgren R, Olsson P, Unge $\mathrm{G}$

This article in PubMed: www.ncbi.nlm.nih.gov/pubmed/6494848

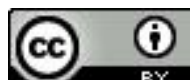




\section{Differences in the respiratory capacity of workers with long-term exposure to vapors from paints free from or containing organic isocyanates}

We have studied the impact of exposure to organic solvents with or without organic isocyanates on the human body. Our aim was to find a test system which was not subject to influence by psychological factors.

Platelets are useful model cells for studies of serotonergic nerve endings (7). A lowered platelet serotonin uptake capacity $\left(\mathrm{V}_{\max }\right)$ has been demonstrated in disorders with a suspected malfunction of central serotonin turnover $(4,5,6)$.

Our results from two pilot studies of the platelet serotonin uptake in car spray painters and graphic workers showed that both groups had a significantly higher uptake $\left(\mathrm{V}_{\mathrm{max}}\right)$ of serotonin (5-hydroxytryptamine) in their platelets in comparison to referents $(1,2)$.

These two studies also involved measurements of the respiratory function. One of the groups consisted of eight men, ages between 21 and 52 years, employed in a car manufacturing industry as spray painters and exposed to vapors from paints containing monomeric organic isocyanates and organic solvents. The subjects in the other group were six men, ages between 34 and 58 years, from a graphic paint plant. They were exposed only to vapors from organic solvents.

Table 1. FEV \% [(100 $\times$ forced expiratory volume in $1 \mathrm{~s}) /$ forced vital capacity] for eight car painters and six graphic workers. (Diff = difference)

\begin{tabular}{lcccc}
\hline $\begin{array}{l}\text { Worker } \\
\text { number }\end{array}$ & $\begin{array}{c}\text { Age } \\
\text { (years) }\end{array}$ & Smoker & & \multicolumn{2}{c}{ FEV\% } \\
\cline { 3 - 4 }
\end{tabular}

\section{Car painters}

\begin{tabular}{rrrrrr}
4 & 35 & - & 84 & 79 & +5 \\
5 & 23 & + & 91 & 84 & +7 \\
6 & 39 & + & 86 & 78 & +8 \\
8 & 51 & - & 90 & 73 & +17 \\
9 & 23 & - & 78 & 84 & -6 \\
10 & 20 & + & 84 & 84 & 0 \\
11 & 36 & - & 81 & 79 & +2 \\
12 & 29 & - & 77 & 81 & -4 \\
Graphic & workers & & & & \\
1 & 58 & + & 68 & 76 & -6 \\
2 & 37 & + & 75 & 80 & -5 \\
3 & 37 & + & 59 & 84 & -25 \\
4 & 57 & - & 67 & 76 & -9 \\
5 & 59 & + & 56 & 78 & -22 \\
6 & 34 & + & 84 & 83 & +1 \\
$3 a^{b}$ & 37 & + & 70 & 84 & -14 \\
\hline
\end{tabular}

a $+=$ smoker, - = nonsmoker.

After reinvestigation after a nonexposure time of six weeks.
The degree of exposure was considered to be moderate in both groups $(1,2)$. A single-breath spirometer (Vitalograph, Siemens-Elema, Sweden) was used. The FEV \% [ $(100 \times$ forced expiratory volume in $1 \mathrm{~s}) /$ forced vital capacity] was calculated, and the difference between the observed and the predicted FEV\% was determined (table 1) (3).

Three subjects in the isocyanate group and five workers in the solvent group were smokers (table 1). In the former group none of the subjects complained of irritation in the airways. In the latter all the test subjects complained of diffuse symptoms of the respiratory tract.

The results from the spirometry tests showed no sign of obstruction of the airways in the isocyanate group. Surprisingly enough there was a positive difference between the observed and the predicted FEV $\%$ of the group. In the solvent-exposed group all but one of the test subjects had a lower FEV \% than predicted, the finding indicating various degrees of obstructive lung disease. The difference between the two groups was statistically significant (twotailed Student's t-test, $\mathrm{p}<\mathbf{0 . 0 2}$ ).

Since many of the subjects were smokers, the possible additional effect of solvent exposure is difficult to evaluate. In the solvent group one nonsmoker and two smokers had restricted capacity. All three were however of an age when respiratory capacity is usually unaffected by smoking.

The present results suggest that the mode of action of the human organism is different for the inhaled vapors from the two types of paint mixtures. Therefore spirometry tests, together with measurements of the kinetic uptake of serotonin in platelets, might be useful for differentiating between the effect of different types of exposure on the organism.

\section{References}

1. Beving $H$, Kristensson J, Malmgren $\mathbf{R}$, Olsson $\mathbf{P}$, Unge G. Effect on the uptake kinetics of serotonin (5-hydroxytryptamine) in platelets from workers with long-term exposure to organic solvents: A pilot study. Scand J Work Environ Health 10 (1984) 229-234.

2. Beving $H$, Malmgren $R$, Olsson $P$, Tornling $G$, Unge G. Increased uptake of serotonin in platelets from car painters occupationally exposed to mixtures of solvents and organic isocyanates. Scand J Work Environ Health 9 (1983) $253-258$.

3. Cotes JE. Lung function: Assessment and application in medicine. Fourth Edition. Blackwell Scientific Publications, Oxford 1982.

4. Malmgren R, Grubbström J, Theorell H, Unge G. Defective serotonin (5-HT) transport mechanism in platelets from patients with endogenous and allergic asthma. Allergy 37 (1982) 29-39. 
5. Malmgren R, Olsson $P$, Tornling $G$, Unge $G$. The 5 -hydroxytryptamine take-up mechanism in normal platelets and platelets from migraine and asthmatic patients. Thromb Res 18 (1980) 733-741.

6. Malmgren $R$, Ásberg $M$, Olsson $P$, Tornling $G$, Unge $G$. Defective serotonin transport mechanism in platelets from endogenously depressed patients. Life Sci 29 (1981) 2649-2658.

7. Pletscher A, Laubscher A. Blood platelets as models for neurons: Uses and limitations. J Neural Transm Suppl 17 (1980) 7-16.

Håkan Beving, $\mathrm{PhD},{ }^{1}$ Rigmor Malmgren, DrMed Sci, ${ }^{1}$ Per Olsson, MD, ${ }^{1}$ Gunnar Unge, $\mathrm{MD}^{2}$

1 Department of Experimental Surgery, Karolinska Hospital S-104 01 Stockholm, Sweden.

2 Department of Thoracic Medicine, Karolinska Hospital, Stockholm S-104 01, Sweden. 